\title{
Analysis of Promoters Recognized by HrpL, an Alternative $\sigma$-Factor Protein from Pantoea agglomerans pv. gypsophilae
}

\author{
Gal Nissan, ${ }^{1}$ Shulamit Manulis, ${ }^{2}$ Dan M. Weinthal, ${ }^{1,2}$ Guido Sessa, ${ }^{1}$ and Isaac Barash ${ }^{1}$ \\ ${ }^{1}$ Department of Plant Sciences, Faculty of Life Sciences, Tel-Aviv University, Tel-Aviv 69978, Israel; ${ }^{2}$ Department of Plant \\ Pathology and Weed Research, ARO, Volcani Center, Bet Dagan 50250, Israel
}

Submitted 15 November 2004. Accepted 4 February 2005.

\begin{abstract}
HrpL, an alternative $\sigma$ factor, activates the transcription of the Hrp regulon by its binding to a common "hrp box" promoter. Based on computational techniques, the hrp box previously was defined as a consensus bipartite cis element,

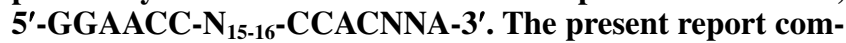
bines a quantitative in vivo assay for measuring Hrp promoter activity with site-specific mutagenesis to analyze the effect of consensus and nonconsensus nucleotides on promoter activity. The analysis was carried out with Hop effectors of the tumorigenic bacterium Pantoea agglomerans pv. gypsophilae, in which HrpL is indispensable for gall formation. Mutational analysis indicates that the hrp box consensus can be divided into crucial and noncrucial nucleotides. The first 5 nucleotides (nt) of the -35 consensus motif (GGAAC) and the $3 \mathrm{nt}$ of the $-\mathbf{1 0}$ motif (ACNNA) are crucial, whereas other consensus and adjacent nonconsensus nucleotides exert a significant effect on the promoter's strength. With spacing of 13 or $17 \mathrm{nt}$ between the two motifs, significant activity was still retained. Gel shift assays indicated that deletion of GG from the $\mathbf{- 3 5}$ consensus motif eliminated HrpL binding, whereas mutations in the $\mathbf{- 1 0}$ consensus motif or modification of the spacing, which eliminates promoter activity, did not elicit any effect. The degeneracy in Hrp promoters of four hrp and type III effector genes of $P$. agglomerans pv. gypsophilae indicated significant differences in promoter activity, whereas increasing the promoter strength of the Hop effector, HsvG, resulted in overexpression of gall formation.
\end{abstract}

Additional keywords: Hrp gene cluster, type III effectors.

Pantoea agglomerans (formerly Erwinia herbicola) pv. gypsophilae incites galls on gypsophila (Cooksey 1986), whereas $P$. agglomerans pv. betae causes galls on beet and gypsophila (Burr et al. 1991). The pathogenicity of both pathovars is dependent on a plasmid designated as $\mathrm{pPATH}_{\text {Pag }}$ and $\mathrm{pPATH}_{\mathrm{Pab}}$ for $P$. agglomerans pvs. gypsophilae and betae, respectively (Manulis and Barash 2003a). The pPATH $_{\text {Pag }}$ has a size of approximately $150 \mathrm{~kb}$ and harbors a pathogenicity island (PAI) of approximately $70 \mathrm{~kb}$. This PAI includes a $\mathrm{hrp} / \mathrm{hrc}$ gene cluster (Mor et al. 2001; Nizan et al. 1997), genes encoding type III virulence effectors (Ezra et al 2000; Guo et al. 2002; Mor et al. 2001; Valinsky et al. 1998), and genes encoding indole 3acetic acid (IAA) and cytokinin biosynthesis (Clark et al.

Corresponding authors: I. Barash; E-mail: isaaci@post.tau.ac.il and S. Manulis; E-mail: shulam@ volcani.agri.gov.il
1993; Gafni et al. 1997; Lichter et al. 1995). Multiple and highly diverse insertion sequence (IS) elements also are interspersed among the virulence genes of the two plasmids (Guo et al. 2002; Lichter et al. 1996). Simultaneous inactivation of IAA and cytokinin biosynthetic genes substantially reduced gall size but did not eliminate gall initiation (Manulis et al. 1998). In contrast, mutations in hrp genes completely abolished gall formation (Nizan et al. 1997), indicating that gall initiation relies on type III effectors, also known as hrp-dependent outer protein (Hop) effectors.

The $h r p / h r c$ genes control the ability of most gram-negative phytopathogenic bacteria to cause disease and to elicit hypersensitive reaction (HR) in resistant and nonhost plants (Lindgren 1997). The hrp gene cluster encodes for components of the type III secretion systems (TTSS), regulatory proteins, and proteinaceous elicitors of HR. The TTSS and Hop effectors both are expressed in response to the environmental conditions in the plant apoplast. The Hop effectors then are delivered directly into the host cells by the TTSS, via the Hrp pilus (Jin et al. 2003). The $h r p$ regulatory cascade of $P$. $a g$ glomerans pv. gypsophilae is composed of the hrpXY operon encoding a two-component system, $h r p S$ encoding a transcriptional factor of the NtrC family, and hrpL encoding an alternative $\sigma$ factor that is a member of the extracytoplasmic factor (ECF) family of $\sigma$ factors (Nizan-Koren et al. 2003). A linear signal transduction cascade that leads to activation of the Hrp regulon via activation of $\mathrm{HrpL}$ in the presence of $\sigma^{54}$ was proposed for $P$. agglomerans pv. gypsophilae (Nizan-Koren et al. 2003). A model that is essentially similar to that of P. agglomerans pv. gypsophilae was proposed for the hrp regulatory cascade of P. stewartii subsp. stewartii (Merighi et al. 2003), whereas different modes of signal transduction were suggested for Erwinia amylovora (Wei et al. 2000) and Pseudomonas syringae (Hutcheson et al. 2002). Regardless of the mechanism involved, the regulatory cascades of all three genera culminate in the activation of HrpL. When HrpL is expressed, it turns on the transcription of $h r p$ genes and type III effectors, presumably by binding to a consensus bipartite cis element ("hrp box") present in the promoter region of all the hrp-controlled genes (Xiao and Hutcheson 1994). Early work on comparative analysis of promoter regions of several $h r p$ and $a v r$ genes identified the consensus hrp box sequence as 5'-GGAACCNA-N ${ }_{13-14^{-}}$ CCACNNA-3' (Innes et al. 1993; Shen and Keen 1993; Xiao and Hutcheson 1994).

Promoter-based screens provide an effective method for identifying Hop effector genes that play a major role in the virulence of phytopathogenic gram-negative bacteria (Greenberg and Vinatzer 2003). The sequencing of the whole genome of 
Pseudomonas syringae pv. tomato DC3000 prompted the development of computational and gene expression techniques to identify virulence-implicated genes downstream of HrpL responsive promoters (Fouts et al. 2002; Zwiesler-Vollick et al. 2002). A key step in this functional genomics approach is the identification of a consensus hrp box-associated promoter that represents existing variations among the various genes encoding for Hrp and Hop effector proteins. Based essentially on alignment of 12 known hrp, hrc, and avr genes in Pseudomonas syringae pv. tomato DC3000, the following consensus bipartite hrp box was generated by Zwiesler-Vollick and associates (2002) for promoter-based screens: 5'-(T/G) GGA (A/G) $\mathrm{C}(\mathrm{C} / \mathrm{T})-\mathrm{N}_{15-16}-\mathrm{CCACNNA}-3^{\prime}$. In another study, 33 promoter regions located upstream of hrp/avr functional genes in Pseudomonas syringae pv. tomato DC3000 and 18 promoter regions identified by reporter transposon screen for HrpL-activated genes were used to create a sequence logo representing the hrp-box promoter (Fouts et al. 2002). The latter was obtained by developing a Hidden Markov Model trained with the Hrp promoter sequences to determine the relative frequencies of bases at every position in the consensus sequence (Schneider and Stephens 1990). The resulting sequence logo (Fouts et al. 2002) showed that 5'-GGAACc and 5'-cCACNNA were the most frequent nucleotides in the -35 and -10 motifs, respectively (lower-case letters indicate lower frequency). In both studies (Fouts et al. 2002; Zwiesler-Vollick et al. 2002), the available Pseudomonas syringae pv. tomato DC3000 genome sequence was searched for genes that contain the hrp box-like sequence in their promoter, and the expression of these genes then was examined, with and without HrpL activation, by microarray and Northern blot analyses.

In spite of previous studies on the identification of Hrp promoters, there have been no reports of a direct interaction of HrpL with $h r p$ box sequences or determination of essential nucleotides within hrp box sequences by site-specific mutagenesis. Such a study might not only unravel the sequence degeneracy present in many known functional Hrp promoters but also could lead to systematic evaluation of promoter activity. The latter cannot be accomplished by comparative studies of Hrp promoters by means of either microarray or Northern blotting (Fouts et al. 2002; Zwiesler-Vollick et al. 2002) because the effect of transcript stability on promoter efficiency cannot be controlled. In the present article, we describe a quantitative in vivo assay for measuring the activity of Hrp promoters based on a direct interaction between HrpL and hrp box sequences. This procedure was used to measure the effects of substitutions at each position in the bipartite Hrp promoter and the spacing between the two motifs on promoter activity. Moreover, the promoter sequence required for binding the $\operatorname{HrpL} \sigma$ protein was identified. Finally, we compared the relative efficiency of native hrp and Hop effector genes in P. agglomerans pv. gypsophilae and showed that the efficiency of Hrp promoters may exert a significant effect on disease expression.

\section{RESULTS}

\section{An in vivo assay for measuring the effect of HrpL} on the Hrp promoters.

An assay involving a two-plasmid system in Escherichia coli that was based on Minogue and associates (2002) was constructed for measuring the transcription activity of hrp box promoters (Fig. 1A). In this assay, plasmid pMBG1 contributed the $h r p L$ coding sequence expressed from the E. coli $\mathrm{P}_{\mathrm{BAD}}$ promoter. The latter was controlled by the $\mathrm{AraC}$ regulator, which also is encoded by pMBG1 as a function of L-arabinose induction (Guzman et al. 1995). Plasmid pMBG2 carries the tested promoter fused in-frame to $l a c Z Y$ reporter gene. Both plasmids were mobilized into an E. coli Top10 host strain and tested for promoter activity.

The virulence genes $h s v G$ and $p t h G$ encode for Hop effectors involved in host specificity and pathogenicity of $P$. agglomerans pv. gypsophilae. HsvG determines host specificity of $P$. agglomerans pvs. gypsophilae and betae on gypsophila (Valinsky et al. 1998, 2002a). PthG has a dual function, acting as a pathogenicity effector on gypsophila and as an Avr effector on beet (Ezra et al. 2002, 2004). The hrp box promoters of these two genes were used to calibrate the abovementioned assay system. Plasmids MBG2-Hs and MBG2-Pt, harboring the promoters of $h s v G$ and $p t h G$, respectively, were transferred to $E$. coli, grown to the same optical density in broth containing various concentrations of L-arabinose, and harvested and assayed for $\beta$-galactosidase. The transcription of both genes started at $0.02 \% \mathrm{~L}$-arabinose and increased proportionally to the L-arabinose concentration until it reached a maximum at $0.2 \%$ (Fig. 1B). Therefore, Luria-Bertani (LB) broth supplemented with $0.2 \%$ L-arabinose was employed for bacterial growth in further experiments conducted to determine the promoter activity. The promoter activity of $p t h G$ was approximately 1.5 times higher than that of $h s v G$ (Fig. 1B).

\section{Mutational analysis of the hrp box promoter.}

The $h r p$ consensus sequence was subjected to various modifications and tested for promoter activity by the two-plasmid in vivo assay described above. The bipartite $h r p$ box promoter sequence of $p t h G$, AAGGAACTG- $\mathrm{N}_{15}$-CCACCGAT (consensus nucleotides are underlined), initially was modified by changing the sixth nucleotide of the -35 motif from $\mathrm{T}$ to $\mathrm{C}$ (MBG2-PTcc) in order to fit the most common consensus sequence. This substitution resulted in an increase of approxi-
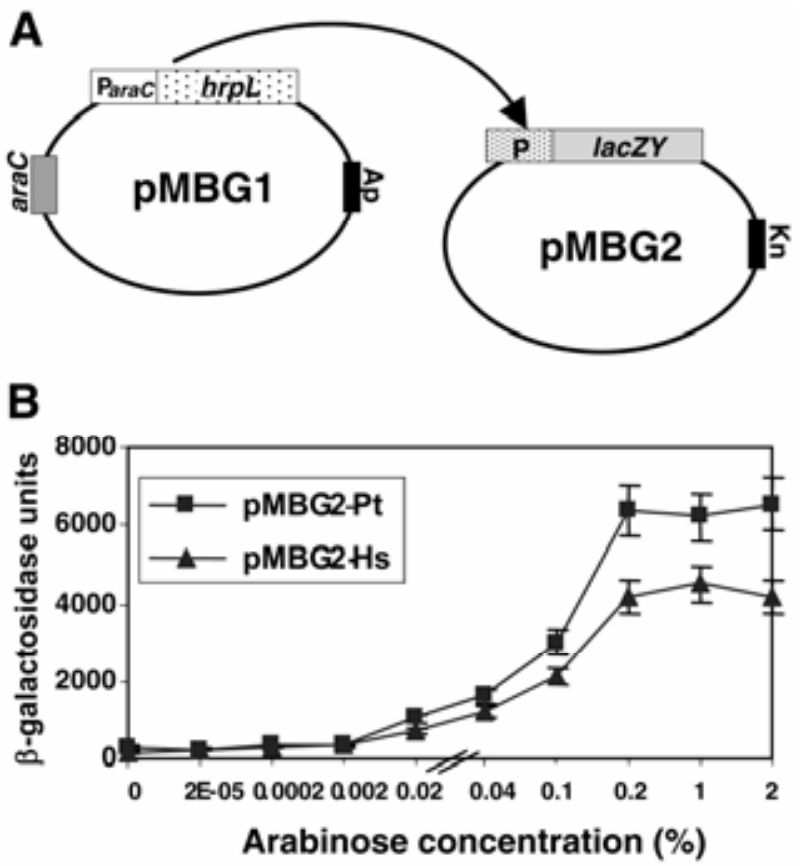

Fig. 1. In vivo assay for measuring activity of Hrp promoter. A, Plasmid pMBG1 containing hrpL under the promoter of ParaC and plasmid pMBG2 containing modified promoters were transferred to Escherichia coli strain (Top10) and used for measuring promoter activity. B, Hrp promoter activity expressed by $\beta$-galactosidase as a function of Larabinose. pthGp-pMBG2-Pt (pthG promoter); hsvGp-MBG2-Hs ( $h s v G$ promoter). Cells were grown in RM broth (1× M9 salts, $1 \mathrm{mM} \mathrm{MgCl}_{2}, 2 \%$ casamino acids, $0.4 \%$ glucose) supplemented with various concentrations of L-arabinose to optical density (at $600 \mathrm{~nm}$ ) of 0.5 . The cells then were harvested and assayed for activity. 
mately $35 \%$ in promoter activity (Fig. 2A, lanes 2 and 3). The modified $p t h G$ consensus sequence then was subjected to sitespecific mutational analysis. Mutations in the -35 motif indicated that the five consensus nucleotides (GGAAC) were essential for promoter activity. Any substitution or deletion of these nucleotides reduced the promoter activity to the level without arabinose (Fig. 2A, lanes 4 through 12). The sixth nucleotide of the consensus was not essential for promoter activity but exerted a significant effect on the promoter's strength. Thus, $\mathrm{C}$ exhibited the highest activity, $\mathrm{T}$ and $\mathrm{A}$ reduced the promoter's activity by approximately 27 and 45\%, respectively, and $G$ exhibited the weakest activity that was only slightly above the control (Fig. 2A, lanes 2, 3, 13, and 14). Interestingly, the first nucleotide downstream to the hrp box, although not considered to be a consensus nucleotide, exhibited a significant effect on the promoter strength. Substitution of any other nucleotide for $\mathrm{G}$ significantly decreased (by approximately $77 \%$, in the case of $\mathrm{C}$ ) the promoter activity in an otherwise perfect consensus hrp box (Fig. 2A, lane 15). Replacing the $\mathrm{G}$ with $\mathrm{A}$ gave similar reductions to its replacement with $\mathrm{C}$ (results not shown). Changes of the nucleotides upstream to the hrp box did not elicit any significant effect on the promoter activity (Fig. 2A, lane 16).

Mutational analysis of the -10 motif indicated that any change in one of the consensus nucleotides ACNNA either completely eliminated the promoter activity or reduced it to a very low level (Fig. 2B, lanes 4 through 7). Modifications of the consensus nucleotides immediately upstream to the latter sequence,
A

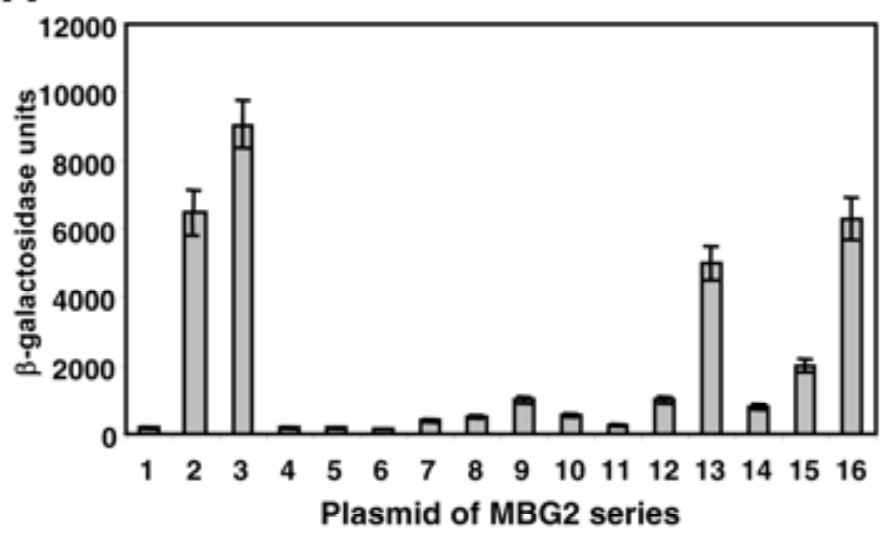

B
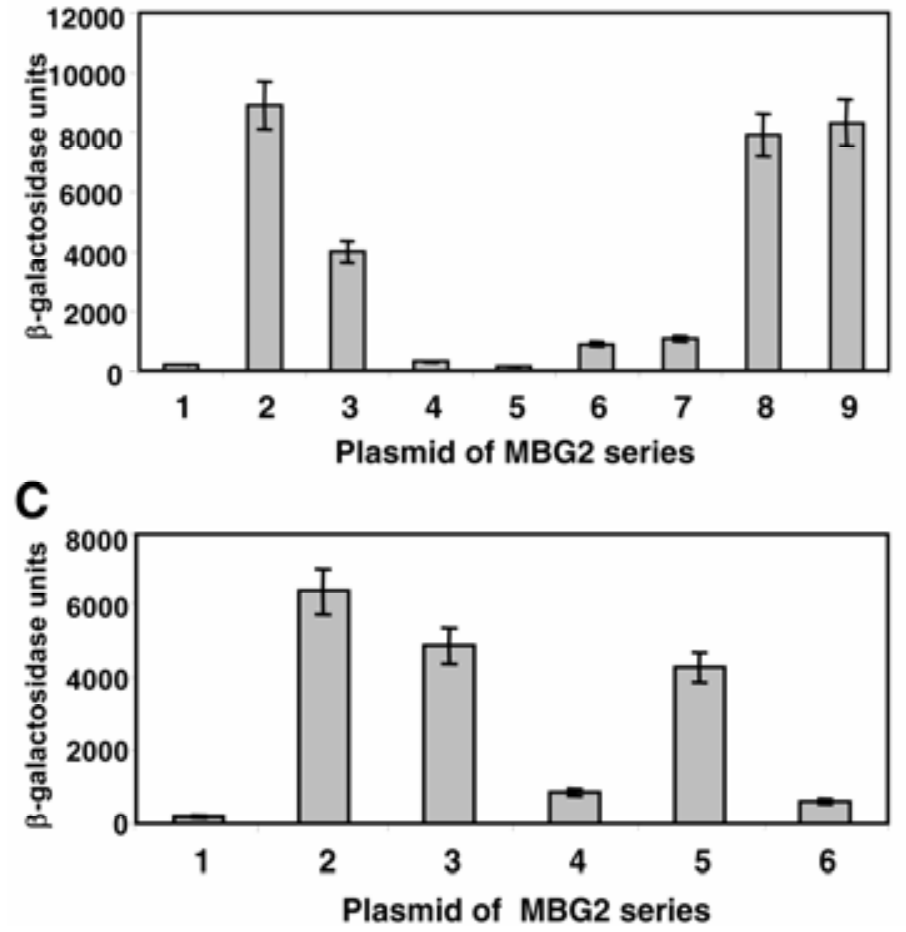

$(1,2) \quad$ MBG2 - Pt AAGGAACTG $\left[N_{15}\right]$ CCACAGAT

(3) MBG2-Pt AAGGAACCG $\left[N_{15}\right] \overline{C C A C A G \bar{T}}$

(4) MBG2-Pt $t_{\Delta r}$ AAGG--CCG $\left[N_{15}\right]$ CCACAGAT

(5) MBG2-Pt $A \overline{A A--A A C C} G\left[N_{15}\right] \overline{C C A C A G A-T}$

(6) MBG2-Pt $t_{A C C}$ AAGGAA-- $G\left[N_{15}\right] \overline{C C A C A G \bar{T}}$

(7) MBG2-Pt $t_{A A}$ AAGGA-CCG $\left[N_{15}\right]$ CCACAGAT

(8) MBG2-Pt $t_{A G}$ AAG-AACCG $\left[\mathrm{N}_{15}\right]$ CCACAGAT

(9) MBG2-Pt $t_{A C}$ A.AGGAC-G $\left[N_{15}\right] \overline{C C A C A G A} T$

(10) MBG2-Pt AAGTAACCG $\left[\mathrm{N}_{15}\right] \overline{\text { CCACAGĀT }}$

(11) MBG2-Pt A.AGGAGCCG $\left[N_{15}\right] \overline{\text { CCACAGĀT }}$

(12) MBG2-Pt TC A.GGAATCG $\left[N_{15}\right]$ CCACAGAT

(13) MBG2-Pt AAGGAACA $\left[N_{15}\right] \overline{\text { CCACAGĀT }}$

(14) MBG2-Pt A.A $\overline{G G A A C G}$ G $\left[N_{15}\right] \overline{\text { CCACAGA }}$

(15) MBG2-Pt $t_{C C C}$ A.AGGAACCC $\left[N_{15}\right]$ CCACAGAT

(16) MBG2-Pt $t_{T T G}$ TT $\overline{\text { GGAACC }}\left[\mathrm{N}_{15}\right] \overline{\mathrm{CCACAG}} \overline{\mathrm{A} T}$
(1) MBG2-Pt AAGGAACTG $\left[\mathrm{N}_{15}\right]$ CCACAGAT

(2) MBG2-Pt $\subset$ A.GGAACCG $\left[N_{15}\right]$ CCACAGAT

(3) MBG2-Pt I AAGGAACCG [N 15$]$ TTACAGAT

(4) MBG2-Pt ${ }_{I 1}$ AAGGAACCG $\left[N_{15}\right]$ CCACAG $\overline{\text { GT }}$

(5) MBG2-Pt $t_{I I I}$ AAGGAACCG $\left[N_{15}\right]$ CCTGAGAT

(6) MBG2-Pt $t_{I V}$ AAGGAACCG $\left[N_{15}\right]$ CCGCAGAT

(7) MBG2-Pt AAGGAACCG $\left[\mathrm{N}_{15}\right] \overline{\mathrm{CC}} \overline{\mathrm{T}} \mathrm{AG} \overline{\mathrm{A}} \mathrm{T}$

(8) MBG2-Pt $t_{V I}$ AAGGAACCG $\left[N_{15}\right]$ CCACGTAT

(9) MBG2-Pt $t_{\mathrm{VII}}$ AAGGAACCG $\left[\mathrm{N}_{15}\right]$ CCACAGAG $\begin{array}{ll}\text { (1) MBG2-Pt } & \text { AAGGAACTG }\left[N_{15}\right] \text { CCACAGAT } \\ \text { (2) MBG2-Pt } & \text { AAGGAACCG }\left[N_{15}\right] \text { CCACAGAT } \\ \text { (3) MBG2-Pt } & \text { AAGGAACCG }\left[\mathbf{N}_{13}\right] \text { CCACAGAT } \\ \text { (4) MBG2-Pt.5 AAGGAACCG }\left[\mathbf{N}_{10}\right] \text { CCACAGAT } \\ \text { (5) MBG2-Pt+2 A.AGGAACCG }\left[\mathbf{N}_{17}\right] \text { CCACAGAT } \\ \text { (6) MBG2-Pt }\end{array}$

Fig. 2. Mutational analysis of the pthG promoter. Escherichia coli cells harboring plasmid of the MBG 2 series were grown in the presence of $0.2 \%$ Larabinose and assayed for $\beta$-galactosidase. Sequence of the tested promoters are listed on the right and their activities monitored by the $\beta$-galactosidase reporter are shown on the left. A, Effect of site-directed mutagenesis in the -35 motif on promoter activity. Lanes 1, control (MBG2-Pt without arabinose); 2,

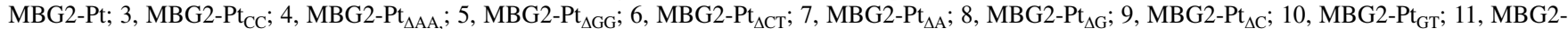

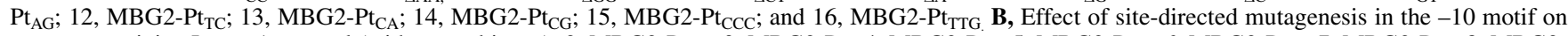

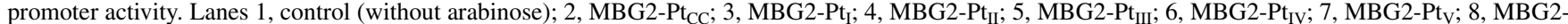
$\mathrm{P}_{\mathrm{VI}}$; and 9, MBG2-Pt $\mathrm{VII}_{\text {. }} \mathbf{C}$, Effect of spacing between the -10 and -35 motifs on promoter activity. Lanes 1 , control (without arabinose); 2, MBG2-Pt $\mathrm{CC}$; 3,

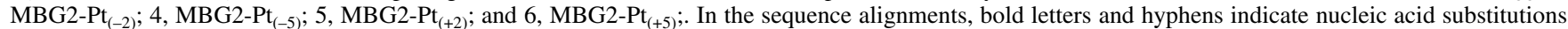
and deletions, respectively. 
$\underline{\mathrm{CC}}$, significantly influenced the promoter strength but did not eliminate activity. Replacing the $\underline{\mathrm{CC}}$ with $\underline{\mathrm{TT}}$ reduced the promoter activity by approximately $\overline{56 \%}$ (Fig. $2 \mathrm{~B}$, lane 3 ). Changing either the nonconsensus nucleotides (NN) or the first nucleotide downstream to the -10 consensus motif did not have any effect on the promoter activity (Fig. 2B, lanes 8 and 9).

Changing the spacing between the two motifs from 15 to 13 or 17 nucleotides (nt) (Fig. 2, lanes 3 and 5) reduced the promoter activity by 45 to $50 \%$. Further decrease or increase in spacing almost eliminated detectible promoter activity (Fig. $2 \mathrm{C}$, lanes 4 and 6). Transcription rates similar to that of the control were observed with a spacing of 14 or 16 nt (results not shown).

\section{Binding of hHrpL to the hrp box DNA.}

A gel shift assay was employed for studies on the interaction of HrpL protein with the hrp promoter DNA of $p t h G$. Purification of $\mathrm{HrpL}$ as a histidine-tagged fusion protein (hHrpL), and the gel shift assay are described (discussed below). The presence of a core RNA polymerase (RNAP) obtained from $E$. coli was mandatory for binding of hHrpL to hrp box DNA (Fig. 3). Neither core RNAP nor hHrpL showed detectable binding to the hrp box DNA in the absence of the other protein (Fig. 3, lanes 1 and 2). No binding was achieved under optimal conditions with control DNA (Fig. 3, lane 3), which indicated specificity in the binding of $\mathrm{hHrpL}$ to the promoter sequence. These data are consistent with hHrpL acting as a $\sigma$ factor (Lonetto et al. 1992).
The promoters of $p t h G$ and $h s v G$ retarded the mobility of the RNAP-hHrpL-DNA complex (Fig. 3, lanes 4 and 5). A mutation in the -10 motif that eliminated $h r p$ box promoter activity of $p t h G$ did not have any significant effect on DNA binding (Fig. 3, lane 6). In contrast, a mutation in the -35 motif (deletion of GG) (Table 1) almost completely eliminated the binding of hHrpL to the pthG promoter (Fig. 3, lane 7). A spacing of either 10 or $20 \mathrm{nt}$, which inactivated promoter activity (Fig. 2C), did not have any significant effect on hHrpL binding (results not shown).

Relationship of $\boldsymbol{h r p}$ promoter activity to disease expression.

The observed degeneracy in $h r p$ box promoters suggests that differential efficiency may exist among these promoters and may even render some nonfunctional. To gain an insight into the extent to which the activity of Hrp promoters may vary within the same pathogen, we compared the relative efficiency of four native Hrp promoters residing on the pPATH $\mathrm{Pag}_{\mathrm{Pag}}$ The selected genes included $h r p J$ and Hop effector genes encoding for AvrPphD, HsvG, and PthG. Mutations in each of these genes resulted in either a complete elimination of gall formation or a significant decrease in gall size (Manulis and Barash 2003a). The hrpJ gene showed the highest promoter activity and $a v r P p h D$ the lowest (Fig. 4). The activity levels of the Hrp promoters of $p t h G, h s v G$, and $a v r P p h D$, relative to that of hrpJ, were $0.77,0.51$, and 0.22 , respectively.

We also examined whether the observed differences in promoter strength had any effect on disease. To answer this ques-

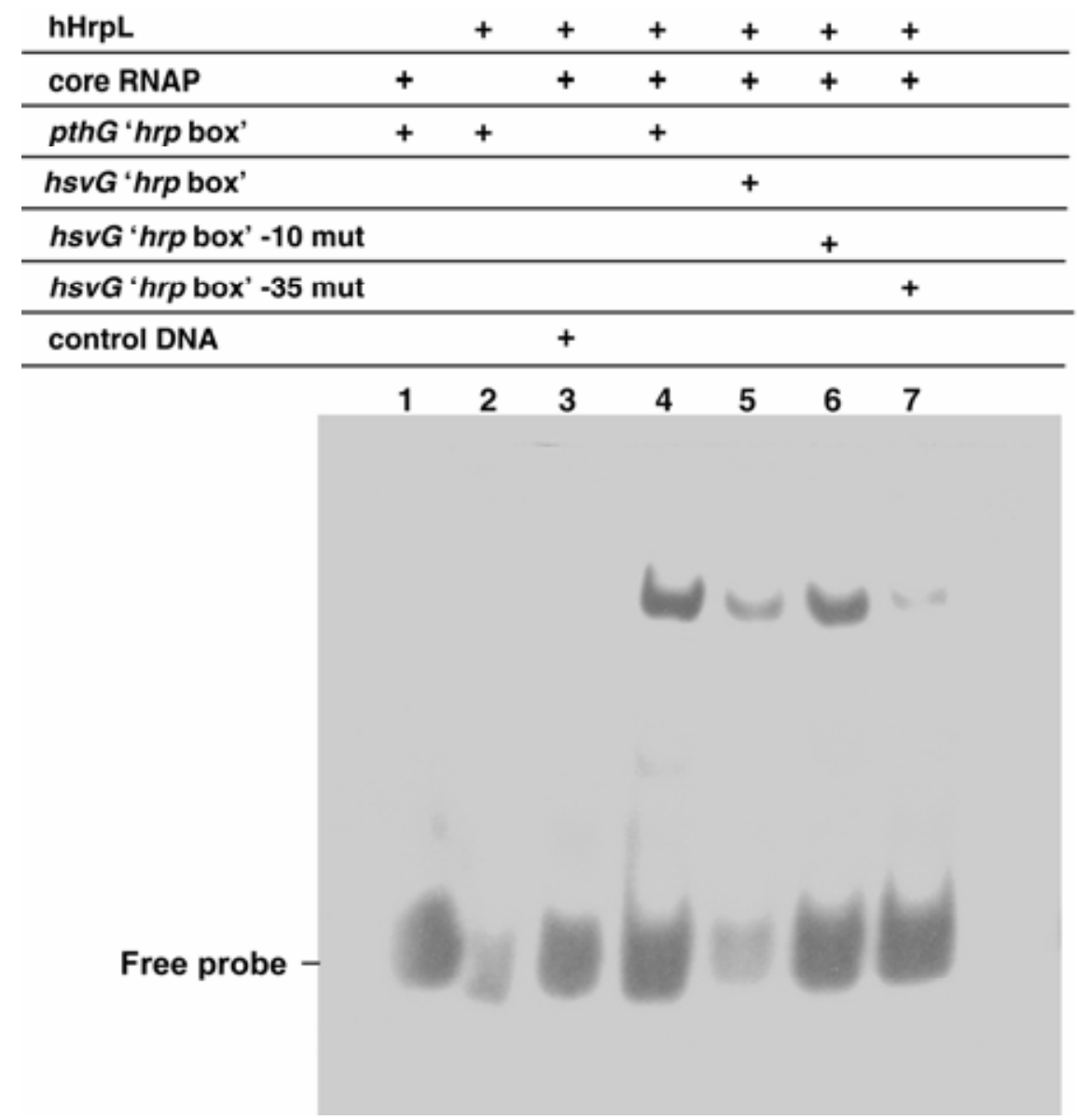

Fig. 3. Gel shift assay of hHrpL with hrp promoter DNA of $p t h G$. Oligonucleotides used to obtain "hrp box" promoters and their mutations are listed in Table 2. Assay procedure is described in Materials and Methods. Lanes 1, Core RNA polymerase (RNAP) with hrp box promoter of pthG (pt-gr); and 2, hHrpL with hrp box promoter (pt-gr). The following lanes contained hHrpL and core RNAP with lane 3, control DNA (DIG Shift Kit, Roche Applied Science); 4, hrp box promoter of $p t h G$ (pt-gr); 5, hrp box promoter of $h s v G$ (hs-gr); 6, hrp box DNA of $p t h G$ mutated in the -10 motif (pt-gr2); and 7, $h r p$ box DNA mutated in the -35 motif (pt-gr1). 
tion, we constructed three different sequences based on the $h s v G$ promoter: hsp1-d (based on hrpJ promoter), hsp2-d (equivalent to $h s v G$ promoter), and hsp3-d (based on avrPphD promoter) (Table 1). The three promoters were fused in frame with the $h s v G$ coding region and cloned into pLAFR3 to yield pHsp1 (strong promoter), pHsp2 (medium-strength promoter), and pHsp3 (weak promoter) (Table 2). These three plasmids then were used to complement the $h s v G$ mutant Pag8241MxB45; pHsp1, pHsp2, and pHsp3 were transformed into Pag824-1MxB45 to yield Pag824-1MxB45/pHsp1, Pag8241MxB45/pHsp2, and Pag824-1MxB45/pHsp3, respectively (Table 2). Gypsophila seedlings then were inoculated with these transconjugants (discussed below). The results clearly demon- strate that exchanging the $h s v G$ promoter with the stronger one caused an increase in gall size (approximately threefold), whereas the weak promoter did not cause gall formation (Table 3; Fig. 5). The appearance of a crown around the cutting edge of the $h s v G$ mutant (Pag824-1MxB45) and the weak promoter (Fig. 5C and E) previously was reported when high bacterial concentration was employed (Valinsky et al. 1998).

\section{DISCUSSION}

In the present study, we have combined a quantitative in vivo assay for measuring Hrp promoter activity with site-directed mutagenesis to analyze the effects of hrp box consen-

Table 1. Sequence of fragments and primers used in this study

\begin{tabular}{|c|c|c|}
\hline $\begin{array}{l}\text { Fragment, } \\
\text { primer }\end{array}$ & Sequence & Used for \\
\hline \multicolumn{3}{|l|}{ Fragments } \\
\hline \multirow[t]{2}{*}{ hs-gr } & 5'-TTTATGCCGGAACCGCCGGGCGGTTTTCGTTACAAAA & Mobility-shift \\
\hline & 3'-AAATACGGCCTTGGCGGCCCGCCAAAAG $\overline{C A A T G T T T T}$ & Assay of $h s v G h r p$ box promoter \\
\hline \multirow{2}{*}{ pt-gr } & 5'-TGCAAGGAACTGAATCCATCCCAGATGCCACAGATTAAAG & Mobility-shift \\
\hline & 3'-ACGTTCC TTGAC TTAGGTAGGGTCTACGGTGTCTAATTTC & Assay of $p t h G h r p$ box promoter \\
\hline \multirow[t]{2}{*}{ pt-gr2 } & 5'-TGCAAAACTGAATCCATCCCAGATGCCACAGATTAAAG & Mobility-shift \\
\hline & 3'-ACGTTTT GACTTAGGTAGGGTCTACGGTGTC TAATTTC & $\begin{array}{l}\text { Assay of } p t h G \mathrm{hrp} \text { box promoter } \\
\text { mutated in the }-35 \text { box }\end{array}$ \\
\hline \multirow[t]{2}{*}{ pt-gr1 } & 5'-TGCAAGGAACTGAATCCATCCCAGATGCCAGATTAAAG & Mobility-shift \\
\hline & 3'-ACGTTCCTTGACTTAGGTAGGGTCTACGGTCTAATTTC & $\begin{array}{l}\text { Assay of } p t h G \text { hrp box promoter } \\
\text { mutated in the }-10 \text { box }\end{array}$ \\
\hline \multicolumn{3}{|l|}{ Primers } \\
\hline hrpl-d & GGCATCCATGGTTAAAGATAGC & Cloning $h r p L$ into: \\
\hline hrpl-r1 & GTTAGATCTAAAGACGGACTGTT & pBAD22 \\
\hline hrpl-r2 & GTAAGATCTGGACTGTTTTAACG & pQE60 \\
\hline hsp1-d & GGGAAGCTTTTATGCCGGAACCGCCGGGCGGTTTTCGCCACAAAAAGAGG & Cloning modified promoter region \\
\hline hsp2-d & GGGAAGCTTTTATGCCGGAACCGCCGGG & into pKS-HsvG \\
\hline hsp3-d & GGGAAGCTTTTATGCCGGAACCCCCGGGCGGTTTTCGCCACAALAAGAGG & \\
\hline hsp-r & CCGGCGGTACCCTGAGGATGCGGG & \\
\hline \multicolumn{2}{|l|}{ MBG2 series } & Creating: \\
\hline avp-d & GAGTCAAGCTTTGGAACCC & pMBG2-avr \\
\hline avp-r & TTGTAAAGCTTTCATAGCGCTATC & \\
\hline hrpj-d & GGAAAAAGTTTAGGGAACCGCAGCG & \\
\hline hrpj-r & AACGGAAGCTTTTTTCATCCTGGCG & pMBG2-hrpj \\
\hline phs-d & GGGAAGCTTTTATGCCGGAACCGCCGGG & \\
\hline phs-r & CCGTAAGCTTTAATGTTGTTCC & pMBG2-Hs \\
\hline ppt-d & GGCCAAGCTTTCGCAAGGAACTGAATC & \\
\hline ppt-r & CGAAGCTTTGAAACATCCC & pMBG2-Pt \\
\hline ppt-cc & GGCCAAGCTTTCGCAAGGAACCGAATC & pMBG2-Pt $\mathrm{CC}_{\mathrm{C}}$ \\
\hline ppt- $\Delta$ gg & GGCCAAGCTTTCGCAAAACCGAATC & pMBG2-Pt $\mathrm{AGG}_{\Delta}$ \\
\hline ppt- $\Delta$ aa & GGCCAAGCTTTCGCAAGGCCGAATC & pMBG2-Pt \\
\hline ppt- $\Delta$ ct & GGCCAAGCTTTCGCAAGGAAGAATC & pMBG2-Pt \\
\hline ppt- $\Delta \mathrm{g}$ & 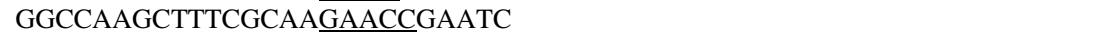 & pMBG2-Pt ${ }_{\Delta \mathrm{G}}$ \\
\hline ppt- $\Delta \mathrm{a}$ & GGCCAAGCTTTCGCAAGGACCGAATC & pMBG2-Pt $\triangle \mathrm{A}$ \\
\hline ppt- $\Delta \mathrm{c}$ & GGCCAAGCTTTCGCAAGGAACGAATC & pMBG2-Pt ${ }_{\Delta C}$ \\
\hline ppt-ag & GGCCAAGCTTTCGCAAGGAGCCGAATC & $\mathrm{pMBG} 2-\mathrm{Pt}_{\mathrm{AG}}$ \\
\hline ppt-gt & 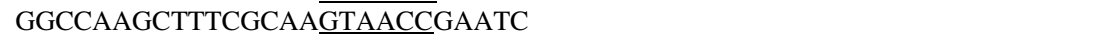 & pMBG2-Pt $t_{\mathrm{GT}}$ \\
\hline ppt-tc & GGCCAAGCTTTCGCAAGGAATCGAATC & $\mathrm{pMBG} 2-\mathrm{Pt}_{\mathrm{TC}}$ \\
\hline ppt-ca & GGCCAAGCTTTCGCAAGGAACAGAATC & pMBG2-Pt $t_{C A}$ \\
\hline ppt-cg & GGCCAAGCTTTCGCAAGGAACGGAATC & $\mathrm{pMBG} 2-\mathrm{Pt}_{\mathrm{CG}}$ \\
\hline ppt-cec & GGCCAAGCTTTCGCAAGGAACCCAATC & pMBG2-Pt $t_{C C C}$ \\
\hline ppt-ttg & GGCCAAGCTTTCGCTT $\overline{\text { GGAACCGAATC }}$ & pMBG2-Pt $\mathrm{TTG}_{\mathrm{TT}}$ \\
\hline ppt-I & GGCCAAGCTTTCGCAAGGAACCGAATCCATCCCAGATGTTACAGATTAAAGT & pMBG2-Pt \\
\hline ppt-II & GGCCAAGCTTTCGCAAGGAACCGAATCCATCCCAGATGCCACAGGTTAAAGT & pMBG2-Pt \\
\hline ppt-III & GGCCAAGCTTTCGCAAGGAACCGAATCCATCCCAGATGCCATAGATTAAAGT & pMBG2-Pt \\
\hline ppt-IV & 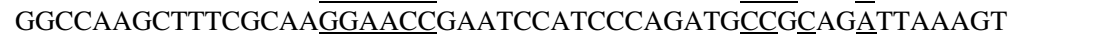 & pMBG2-Pt $\mathrm{Pt}_{\mathrm{IV}}$ \\
\hline ppt-V & 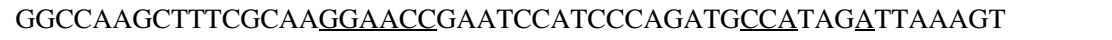 & pMBG2-Pt $t_{\mathrm{V}}$ \\
\hline ppt-VI & GGCCAAGCTTTCGCAAGGAACCGAATCCATCCCAGATGCCACGTATTAAAGT & pMBG2-Pt \\
\hline ppt-VII & 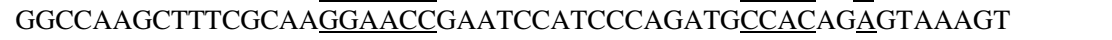 & pMBG2-Pt \\
\hline ppt- $(-2)$ & 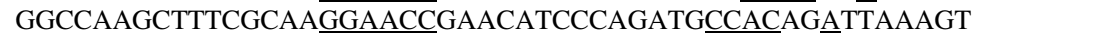 & pMBG2-Pt $(-2)$ \\
\hline ppt- $(-5)$ & GGCCAAGCTTTCGCAA $\overline{\text { GGAACC } G A A C A T C C A T G C C A C A G A T T A ̄ A A G T ~}$ & pMBG2-Pt $(-5)$ \\
\hline ppt- $(+2)$ & 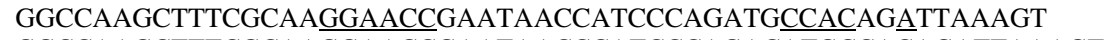 & pMBG2-Pt $(+2)$ \\
\hline ppt- $(+5)$ & GGCCAAGCTTTCGCAAGGAACCGAATAACCCATCCCAGACATGCCACAGÄTTAAAGT & pMBG2-Pt $(+5)$ \\
\hline
\end{tabular}


sus and nonconsensus nucleotides on promoter activity. The dependency of the promoter activity on arabinose concentration in our two-plasmid system suggests a direct interaction between HrpL and the promoter. The same transcript (lacZY) was employed with the different promoters; therefore, the assay was independent of transcript stability. The consensus bipartite $h r p$ box promoter (i.e., GGAACC-N ${ }_{15-16}$ - $\underline{\text { GACNNA }}$ has been generated previously by alignment of promoter regions from functional $h r p / h r c$ and $a v r$ genes obtained from Pseudomonas syringae strains (Fouts et al. 2002; Innes et al. 1993; Shen and Keen 1993; Xiao and Hutcheson 1994; ZwieslerVollick et al. 2002). In the present study, the analysis was performed with HrpL of Pantoea agglomerans, which exhibits only $52 \%$ similarity to HrpL of Pseudomonas syringae pv. tomato. Nevertheless, the results obtained are relevant to hrp box promoters of Pseudomonas syringae as well as to Er- winia spp., because the hrp box consensus nucleotides seem to be common to all the HrpL-dependent phytopathogenic bacteria. Moreover, some type III effectors (e.g., AvrPphD, HopPmaB, and HopPmaH) are common to Pantoea agglomerans pv. gypsophilae and Pseudomonas syringae and, presumably, have been acquired by horizontal gene transfer (Manulis and Barash 2003b).

The present study demonstrates that the hrp box consensus can be divided into crucial and noncrucial nucleotides. The first $5 \mathrm{nt}$ of the -35 consensus motif (GGAAC) and the last 3 nt of the -10 consensus motif ( $\underline{\mathrm{ACNN}} \underline{\mathrm{A}})$ cannot be replaced. The sixth nucleotide of the -35 consensus motif $(\mathrm{C})$ and the first $2 \mathrm{nt}$ of the -10 consensus motif $(\underline{\mathrm{CC}})$ can be replaced with other nucleotides; however, their replacement caused a significant reduction of promoter activity in a differential manner. An unexpected result was the effect of the first nu-
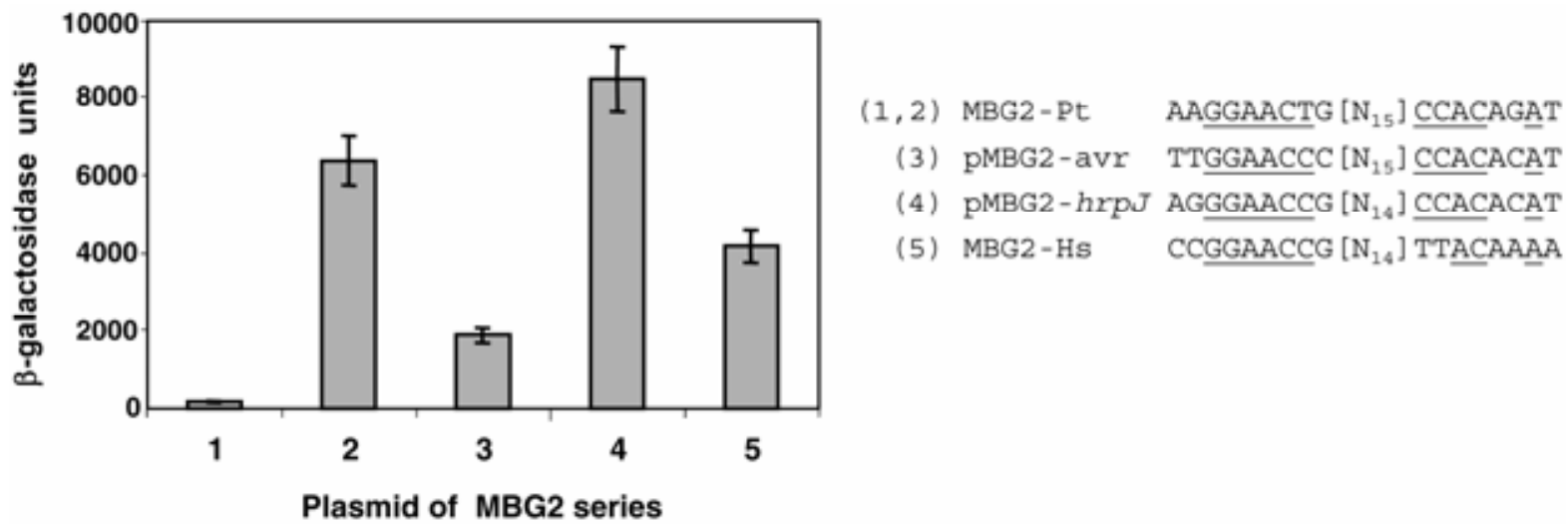

Fig. 4. Comparative activity of native "hrp box" promoters from Pantoea agglomerans pv. gypsophilae. Sequence of the tested promoters are listed on the right and their activities monitored by the $\beta$-galactosidase reporter are shown on the left. In the sequence alignments, bold letters and hyphens indicate nucleic acid substitutions and deletions, respectively; $1=p t h G p$ (without arabinose), $2=p t h G p(\mathrm{MBG} 2-\mathrm{Pt}), 3=\operatorname{avrPphDp}(\mathrm{MBG} 2$-avr), $4=h r p J p(\mathrm{MBG} 2-$ hrpJ), and $5=h s v G p(\mathrm{MBG} 2-\mathrm{Hs})$.

Table 2. Bacterial strains, cosmids, and plasmids used in this study

\begin{tabular}{|c|c|c|}
\hline Strains, plasmids ${ }^{\mathbf{a}}$ & Relevant characteristics $^{\mathrm{b}}$ & Reference or source \\
\hline \multicolumn{3}{|l|}{ Strains } \\
\hline Top10 & Escherichia coli, lacZ4M15 $\Delta l a c X 74$ araD139 $\Delta$ (ara-leu) 7697 & Invitrogen \\
\hline DH5 $\alpha$ & E. coli, lacZ $\Delta \mathrm{M} 15 \Delta$ (lacZYA-argF)U169 gyrA96 & Invitrogen \\
\hline M15 (pREP4) & Lac, ara, gal, mtl, recA ${ }^{\mathrm{r}}$, uvrr , (pREP4: lacI, kan $^{\mathrm{r}}$ ) & Qaigen \\
\hline MBG2 series & E. coli Top10 (pMBG1, pMBG2) & This study \\
\hline Pag 824-1 & Wild-type pathogenic strain with Rif $^{\mathrm{T}}$, gypsophila pathovar & Manulis 1991 \\
\hline PagMxB45 & Pag 824-1, marker exchange mutants on $h s v G$ & Valinsky et al. 1998 \\
\hline Pag 824-1Mx B45/pHsp1 & Pag 824-1Mx B45 transformed with pHsp1 & This study \\
\hline Pag 824-1Mx B45/pHsp2 & Pag 824-1Mx B45 transformed with pHsp2 & This study \\
\hline Pag $824-1 \mathrm{Mx}$ B45/pHsp3 & Pag 824-1Mx B45 transformed with pHsp3 & This study \\
\hline \multicolumn{3}{|l|}{ Cosmids } \\
\hline pLAFR3 & $\mathrm{Tc}^{\mathrm{r}}$, broad-host-range vector IncP-1 rixRK2+ lacZa Tra- Mob+ cos & Staskawicz 1987 \\
\hline pHsp1 & $\mathrm{Tc}^{\mathrm{r}}, h s v G$ under strong $h r p$ box promoter cloned into pLAFR3 as an HindIII/ BamHI fragment & This study \\
\hline pHsp2 & $\mathrm{Tc}^{\mathrm{r}}, h s v G$ under medium $h r p$ box promoter cloned into pLAFR3 as an HindIII/ BamHI fragment & \\
\hline & & This study \\
\hline pHsp3 & $\mathrm{Tc}^{\mathrm{r}}, h s v G$ under weak $h r p$ box promoter cloned into pLAFR3 as an HindIII/ BamHI fragment & This study \\
\hline \multicolumn{3}{|c|}{ 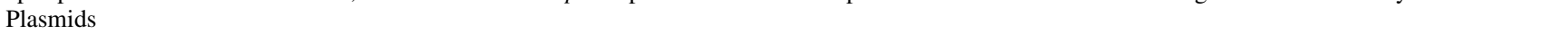 } \\
\hline pQE60 & $\mathrm{Ap}^{\mathrm{r}}$, His-tag expression vector & Qiagen \\
\hline pBluescript-II KS+ & $\mathrm{Ap}^{\mathrm{r}}$, cloning vector, ColE1 ori & Stratagene \\
\hline pBAD22 & $A p^{r}$, arabinose inducible expression vector & Guzman et al. 1995 \\
\hline pBBR1MCS-3 & $\mathrm{Tc}^{\mathrm{r}}$, broad range expression vector & Kovach et al. 1995 \\
\hline pLKC480 & Source of $l a c Z Y-K^{r}$ cassette & Tiedeman and Smith 1988 \\
\hline pHrpL-His & PCR-amplified $h r p L$ coding sequence cloned into pQE60 as a $N c o \mathrm{I} / B a m \mathrm{HI}$ fragment & This study \\
\hline pMBG1 & PCR-amplified $h r p L$ coding sequence cloned into pBAD22 as a $N c o \mathrm{I} / H i n \mathrm{dIII}$ fragment & This study \\
\hline pBB-lacZ & The lacZYKm cassette cloned as an XmaI fragment into pBBR1MCS-3 & This study \\
\hline pMBG2 series & $\begin{array}{l}\text { Various PCR-amplified } h r p \text { box promoter and partial coding sequence cloned into pBB-lacZ as } \\
\text { HindIII fragments }\end{array}$ & This study \\
\hline pKS-HsvG & $\begin{array}{l}\text { PCR-amplified } h s v G \text { coding sequence and promoter cloned into pBluescript-II KS as an } \\
\text { HindIII/Bam HI fragment }\end{array}$ & This study \\
\hline
\end{tabular}

\footnotetext{
${ }^{\text {a }}$ Pag = Pantoea agglomerans pv. gypsophilae.
}

${ }^{\mathrm{b}} \mathrm{Tc}=$ tetracycline, $\mathrm{Rif}=$ rifampicin, $\mathrm{Ap}=$ ampicillin, $\mathrm{Km}=$ kanamycin, $\mathrm{PCR}=$ polymerase chain reaction. 
cleotide downstream to the -35 consensus motif on promoter activity: $G$ exhibited the highest activity, whereas all the other nucleotides exhibited substantially reduced promoter activity (by 70 to $85 \%$ ) even in the presence of a perfect nucleotide consensus in the -35 motif. It is noteworthy that $\mathrm{G}$ appears in this site of Hrp promoters more frequently than the other nucleotides. For example, of 33 Hrp promoters of hrp/avr functional genes in Pseudomonas syringae pathovars and 18 promoter regions identified in Pseudomonas syringae pv. tomato 3000 by a reporter transposon screen for HrpLactivated genes, 54\% contained $\mathrm{G}$ immediately downstream to the -35 motif, whereas the percentages of $\mathrm{C}, \mathrm{A}$, and $\mathrm{T}$ were 20, 20 and 6\%, respectively (Fouts et al. 2002). Our promoter assay analyses indicate that, although the highest activity was obtained when there was a spacing of 14 to $16 \mathrm{nt}$ between the two conserved motifs, this spacing was not critical, contrary to what has been reported elsewhere (ZwieslerVollick et al. 2002). Although a decrease of the spacing to 13 $\mathrm{nt}$ or an increase to $17 \mathrm{nt}$ caused a significant reduction in promoter activity, the promoters still retained approximately $65 \%$ of their maximal activity.

The absolute need of RNAP for HrpL binding to hrp box promoters is in accordance with its function as a $\sigma$ factor. Interestingly, deletion of $\underline{\mathrm{GG}}$ from the -35 consensus motif was sufficient to eliminate HrpL binding completely, whereas neither mutation in the -10 motif nor reduction or extension of the spacing between the two motifs had any effect on HrpL binding, although it entirely inactivated promoter activity.

Table 3. Effect of Hrp promoter activity on gall size

\begin{tabular}{|c|c|}
\hline Mutant strain ${ }^{\mathrm{a}}$ & Gall fresh weight $(\mathbf{m g})^{b}$ \\
\hline Pag 824-1 (wild-type) & $43(16)$ \\
\hline Pag 824-1Mx B45 (hsv $G^{-}$mutant) & $19(11)$ \\
\hline Pag 824-1Mx B45/pHsp1 & $139(22)$ \\
\hline Pag 824-1Mx B45/pHsp2 & $38(14)$ \\
\hline Pag 824-1Mx B45/pHsp3 & $17(7)$ \\
\hline
\end{tabular}

${ }^{\mathrm{a}}$ Pag $=$ Pantoea agglomerans $\mathrm{pv}$. gypsophilae. $\mathrm{pHsp} 1, \mathrm{pHsp} 2$, and $\mathrm{pHsp} 3$ denote strong, medium-strength, and weak Hrp promoters, respectively. The promoters were cloned into pLAFR3 and used to complement Pag 824-1Mx B45 (hsv $G^{-}$mutant).

${ }^{\mathrm{b}}$ Results are expressed as fresh weight of gall tissue taken 10 days after inoculation and represent one of two different experiments and are given as a mean \pm standard deviation of eight plants.
HrpL is a member of the ECF $\sigma$ factors that regulate and respond to extracytoplasmic functions and direct transcription of specific regulons during unusual physiological conditions, such as stress response and pathogenesis (Bashyam and Hasnain 2004). Members of the ECF subfamily are composed of small (approximately $20 \mathrm{kDa}$ ) proteins that exhibit remarkable diversity in their primary structures (Lonetto et al. 1994) and that have been classified as a subfamily of the $\sigma^{70}$ family (Bashyam and Hasnain 2004; Helmann and Chamberlin 1988).

Limited proteolysis studies have led to a view of the $\sigma$ factor structure as a series of compact domains connected by flexible linkers of variable lengths and sequences (Lonetto et al. 1992; Severinova et al. 1996). This type of architecture lends itself to conformational changes, and biochemical and biophysical probes have indicated that $\sigma$ undergoes substantial conformational changes during the transcription initiation process (Callaci et al. 1999). The $\sigma 70$ family of proteins comprises four domains (Helmann and Chamberlin 1988; Lonetto et al. 1992) but we could identify only two $\left(\sigma_{2}\right.$ and $\sigma_{4}$ ) in the HrpL of Pantoea agglomerans pv. gypsophilae or Pseudomonas syringae pv. tomato. There are distinct differences between the respective DNA binding domains; $\sigma_{2}$ binds to the -10 promoter region, whereas $\sigma_{4}$, which encodes for helix-turn-helix motif, binds to the -35 promoter region (Lonetto et al. 1992). The promoter specificity is determined by the -35 motif, which differs among promoters that are recognized by different ECF $\sigma$ factors in the same bacterial species (Lonetto et al. 1992). HrpL-dependent phytopathogenic bacteria share identical -35 motifs of hrp box promoters; therefore, a high similarity among the $\sigma_{4}$ domain of HrpL would be expected. Thus, the percentage similarities of amino acids between the $\sigma_{4}$ domain of HrpL from Pantoea agglomerans pv. gypsophilae and those from Erwinia amylovora, E. chrysanthemi, and Pseudomonas syringae pv. tomato are 85,75 , and $60 \%$, respectively. In contrast, the similarity with $p v d S$, an ECF factor essential for siderophore biosynthesis in Pseudomonas aeruginosa, is $47 \%$ related (Wilson et al. 2001). It is noteworthy that a deletion of GG in the -35 hrp box motif prevents hHrpL binding, presumably via the $\sigma_{4}$ domain, indicating a high degree of specificity. A crystal structure of the $\sigma_{4}$ domain complexed with the -35 element recently has been demonstrated (Campbell et al. 2002).

Because coordination of virulence factors is necessary for a successful pathogenic process, the expression of these fac-
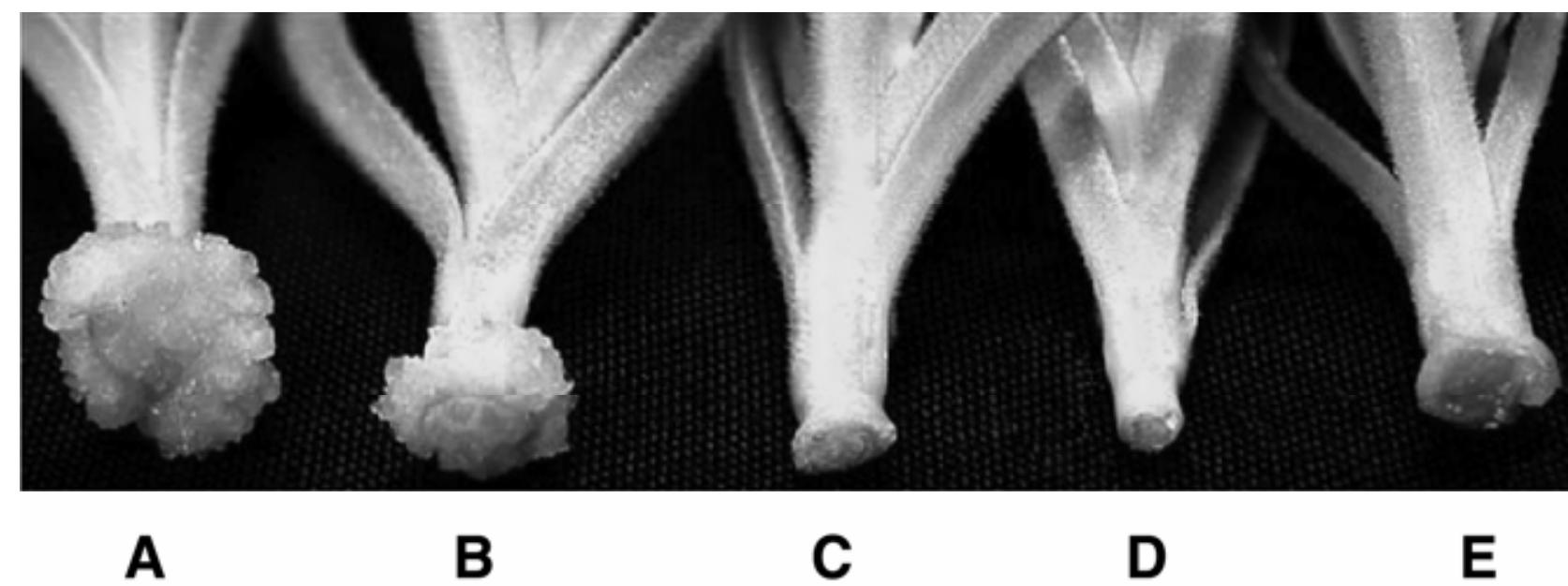

Fig. 5. Phenotypic expression of hsvG under different promoters. Gypsophila cuttings were inoculated with hsvG mutant (Pantoea agglomerans pv. gypsophilae [Pag]824-1MxB45) and its transconjugants. A, Pag824-1MxB45/pHsp1 (strong promoter equivalent to hrpJp); B, Pag824-1MxB45/pHsp2 (medium-strength promoter based on $h s v G p$ ); C, Pag824-1MxB45/pHsp3 (weak promoter equivalent to avrPphDp); D, water control; E, Pag824-1MxB45. Inoculations were carried out with $10^{9} \mathrm{CFU} / \mathrm{ml}$ and the photograph was taken after two weeks. 
tors generally is tightly regulated. Transcriptional regulation is a major mechanism for control of gene expression in bacteria and is influenced mainly by the efficiency of the promoter and the steady-state transcript levels. The degeneracy observed in Hrp promoters could represent a mechanism for fine tuning that is necessary for expressing components of the type III system and Hop effectors in a concerted manner. This adjustment may be provided by the nonconsensus or consensus nucleotides that affect the promoter strength without impeding its function. Genes controlled by the Hrp regulon generally are located in PAIs that presumably have been acquired by the pathogen through one or more horizontal genes transfers (Arnold et al. 2003; Hacker and Kaper 1999). It is reasonable to hypothesize that during the evolution or horizontal gene transfer of the PAI, its virulence genes underwent genetic rearrangements that were followed by selection pressure that affected the composition of Hrp promoters. Thus, it is not surprising to find that the bacterial genome contains Hrp promoters that differ in their activity, as well as nonfunctional promoters. However, functional Hrp promoters have to comply with appropriate transcript stability and the role of the virulence gene in pathogenicity. Comparison of four native Hrp promoters obtained from the $\mathrm{pPATH}_{\mathrm{Pag}}$ (Fig. 4) illustrates the variation in promoter efficiency within the same organism. Thus, the promoter of hrpJ is 4.5 times as efficient as that of avrPphD. Both promoters have identical and perfect consensus in the two motifs of the hrp box, and the difference in strength can be attributed to a difference of a single nucleotide downstream to the -35 consensus motif ( $\mathrm{G}$ in $h r p J$ versus $\mathrm{C}$ in $a v r P p h D$ ), which could account for a decrease of approximately $77 \%$ in promoter strength. The difference in promoter activity between $h r p J$ and $h s v G$ can be attributed to a change in the -10 motif (from CC to TT).

The relationship between gall size and promoter activity of $h s v G$ implies that expression of this gene is a limiting factor in gall development. HsvG was characterized in $\mathrm{pPATH}_{\mathrm{Pag}}$ and pPATH $_{\text {Pab }}$ as a host-specific Hop effector (Valinsky et al. 1998, 2002a,b). Mutations in $h s v G$ eliminated the ability of Pantoea agglomerans pvs. gypsophilae and betae to cause gall formation on gypsophila but did not diminish the pathogenicity of $P$. agglomerans $\mathrm{pv}$. betae on beet or of HR of both pathovars on tobacco. The function of $\mathrm{HsvG}$ is not yet known, but preliminary results of studies in which HsvG was used as a bait for screening the cDNA library of $P$. agglomerans pv. gypsophilae-infected gypsophila seedlings in a yeast two-hybrid system indicated the presence of an activation domain (G. Nissan, S. Manulis, and I. Barash, unpublished data). This led us to hypothesize that HsvG may act as a DNA-binding protein and a potential transcription factor. In the latter case, it might exert its effect by activating several genes simultaneously. Overgrowth of gall tissue in gypsophila cuttings previously was reported to result from overproduction of cytokinins (Lichter et al. 1995), and it is attractive to speculate that HsvG may influence either the production of cytokinins or the sensitivity of plant tissues to these hormones.

Interestingly, AvrPphD previously was reported as a virulence effector of $P$. agglomerans pv. gypsophilae on gypsophila, because a mutant of this gene reduced gall size (Guo et al. 2002). Nevertheless, an equivalent promoter of this gene was insufficient to express $\mathrm{HsvG}$ function during gypsophila infection by $P$. agglomerans pv. gypsophilae (Table 3 ). These results could be attributed to either a difference in mRNA stability between the two genes or a need for higher effector concentration for expressing a phenotype, or both. Regardless of the mechanism involved, the present results demonstrate that the efficiency of Hrp promoters may serve as a significant factor in disease expression.

\section{MATERIALS AND METHODS}

Bacterial strains, plasmids, and growth conditions.

The bacterial strains, cosmids, and plasmids used in the present study are listed in Table 2 . A rifampicin-resistant wildtype strain of P. agglomerans pv. gypsophilae (Pag824-1) and its derivatives were used throughout. Bacteria were grown either in LB broth and agar or in a minimal A medium (Ausubel et al. 1995) with appropriate antibiotics, at $28^{\circ} \mathrm{C}$. Escherichia coli strains DH5 $\alpha$ (Life Technologies, Gaithersburg, MD, U.S.A.), M-15 (Qiagen, Basel, Switzerland), and Top10 (Invitrogen, Basel, Switzerland) were used as cloning hosts and grown at $37^{\circ} \mathrm{C}$ on nutrient agar plates, LB broth, or RM medium ( $1 \times \mathrm{M} 9$ salts, $1 \mathrm{mM} \mathrm{MgCl} 2,2 \%$ casamino acids, $0.4 \%$ glucose) in the presence of ampicillin (Ap) at $100 \mu \mathrm{g} \mathrm{ml}^{-1}$ and kanamycin $(\mathrm{Km})$ at $10 \mu \mathrm{g} \mathrm{ml}^{-1}$, where applicable. Additional antibiotics were used in the following concentrations: rifampicin (Rif) at $100 \mu \mathrm{g} / \mathrm{ml}$, spectinomycin (Spec) at $100 \mu \mathrm{g} / \mathrm{ml}$, and tetracycline (Tc) at $15 \mu \mathrm{g} / \mathrm{ml}$.

\section{Recombinant DNA techniques and plasmid constructions.}

DNA isolation, agarose gel electrophoresis, subcloning, electroporation, Southern blotting, and polymerase chain reaction (PCR) were performed according to standard procedures (Ausubel et al. 1995; Sambrook et al. 1989) or as recommended by the relevant supplier. DNA fragments were amplified by PCR, with Taq polymerase (Sigma-Aldrich, St. Louis) and synthetic oligonucleotides (Table 1), synthesized according to specification (Sigma-Aldrich). For plasmid constructions, the $h r p L$ gene was amplified with PCR primers hrpl-d and hrpl-r2 (Table 1) to create a 5' NcoI cloning site that overlapped and included the ATG translation initiation codon, and a 3' HindIII site downstream of the stop codon. This fragment was inserted into the similarly digested expression vector, pBAD22 (Guzman et al. 1995), resulting in plasmid pMBG1 (Fig. 1A). The $l a c Z Y K m^{\mathrm{r}}$ cassette from plasmid pLKC481 (Tiedman and Smith 1988) was inserted into the broad-host-range vector, pBBR1MCS-3 (Kovach et al. 1995), and cloned as an XmaI fragment into the internal SmaI site to generate plasmid pBB-lacZ (Table 2). This plasmid was used to create an in-frame reporter gene fusion by inserting PCR-amplified promoters and partial coding sequences of $h s v G$, pthG, or other tested promoters with an HindIII primer site used to generate the $\mathrm{pMBG} 2$ series (Table 2). MBG1 and MBG2 were electrophoresed into an E. coli Top10 host strain that was used for analyzing promoter activity.

HrpL was purified as an His-tagged fusion protein as follows. A DNA fragment extending from the ATG start codon of $h r p L$ to 3 bp upstream to the stop codon was amplified by PCR with primers hrpl-d and hrpl-rl (Table 1) and cloned into the His-tag expression vector pQE60 (Qaigen, Basel, Switzerland) to generate $\mathrm{pHrpL}$-his (C-terminus). The $\mathrm{C}$-terminal tagging was preferred because this region is highly divergent in ECF factors, both in length and in sequence, indicating that structural tolerance is to be expected in this protein domain.

\section{$\beta$-Galactosidase activity assay.}

E. coli Top10 harboring a plasmid of the MBG2 series was grown overnight in RM minimal medium. The cells then were diluted to an optical density at $600 \mathrm{~nm}\left(\mathrm{OD}_{600}\right)$ of 0.05 in fresh $\mathrm{RM}$ medium and allowed to grow to an $\mathrm{OD}_{600}$ of 0.1 before Larabinose was added. $\beta$-Galactosidase activity, expressed in enzyme units (Sambrook et al. 1989), was measured after the cells reached an $\mathrm{OD}_{600}$ of 0.5 . Each experiment was performed in triplicate and was repeated at least twice. 
Expression and purification of hHrpL protein.

pHrpL-his was transformed into E. coli $\mathrm{M}-15$ and the bacteria were grown in $\mathrm{LB}(100 \mathrm{ml})$ containing Ap until an $\mathrm{OD}_{600}$ of 0.5 was reached. Following addition of isopropyl- $\beta$-D-thiogalactoside to a final concentration of $1 \mathrm{mM}$, the culture was incubated for an additional $3 \mathrm{~h}$ to induce the expression of the hrpL-his gene. The bacteria then were harvested by centrifugation, resuspended in $60 \mathrm{ml}$ of water, and lysed by freezing and thawing. The lysate was sonicated on ice and centrifuged $(22,000 \times g, 20$ $\mathrm{min})$. The insoluble pellet was washed twice with a washing buffer (25\% [wt/vol] sucrose, $5 \mathrm{mM}$ EDTA, $1 \%$ [vol/vol] Triton $\mathrm{X}-100$ in phosphate-buffered saline). The pellet then was suspended in $5 \mathrm{ml}$ of denaturing solution $(6 \mathrm{M}$ guanidinium hydrochloride; $0.1 \mathrm{M}$ Tris- $\mathrm{HCl}$ buffer, $\mathrm{pH} 8.0 ; 1 \mathrm{mM}$ EDTA, $\mathrm{pH}$ 8.0; and $0.03 \mathrm{M} \beta$-mercaptoethanol for $1 \mathrm{~h}$ at $25^{\circ} \mathrm{C}$ ) (Turkov et al. 1997). Protein renaturation was initiated by 20 -fold dilution in $0.2 \mathrm{M}$ ammonium acetate $(\mathrm{pH} 8.5)$. After $48 \mathrm{~h}$ at $15^{\circ} \mathrm{C}$, the insoluble protein was removed by filtration through a $1-\mathrm{mm}$ Whatman filter paper and the soluble protein was precipitated with $55 \%$ saturated ammonium sulfate overnight. The precipitate was collected by filtration through a GF/C Whatman filter and solubilized in $7 \mathrm{ml}$ of $10 \mathrm{mM}$ Tris- $\mathrm{HCl}(\mathrm{pH} \mathrm{8.0)}$.

\section{Gel retardation assay.}

The synthetic DNA fragments used in these assays are listed in Table 1. Double-stranded DNA was obtained by mixing complementary oligodeoxyribonucleotides, heating to $95^{\circ} \mathrm{C}$, and slowly cooling to room temperature. These DNAs were labeled with digoxigenin (DIG) with a DIG-labeling kit (Roche Molecular Biochemicals, Mannheim, Germany). Core RNAP (Epicentre Technologies, Madison, WI, U.S.A.) was incubated on ice for $10 \mathrm{~min}$ with the purified HrpL protein. Core $\sigma$ mixtures then were added to reaction tubes containing the DNA probe (100 fmol), assay buffer (100 mM Hepes, $\mathrm{pH}$ 7.6; $5 \mathrm{mM}$ EDTA; $50 \mathrm{mM}\left(\mathrm{NH}_{4}\right)_{2} \mathrm{SO}_{4} ; 5 \mathrm{mM}$ dithiothreitol; $1 \%$ [wt/vol] Tween 20 , and $150 \mathrm{mM} \mathrm{KCl}$ ) to give a final volume of $20 \mathrm{ml}$. Following incubation at $28^{\circ} \mathrm{C}$ for $15 \mathrm{~min}$ and standing at room temperature for $5 \mathrm{~min}$, the samples were loaded onto a $5 \%$ native polyacrylamide gel containing Trisborate EDTA (TBE) (22 mM Tris- $\mathrm{HCl}, \mathrm{pH} 8.0,23 \mathrm{mM}$ boric acid, $0.65 \mathrm{mM}$ EDTA) and 5\% bis-acrylamide, and were electrophoresed in TBE. DNA probes were transferred from the gel to an $\mathrm{N}+$ nylon membrane and detected with anti-DIG antibodies according to the manufacturer's protocol (Roche Molecular Biochemicals).

\section{ACKNOWLEDGMENTS}

This study was supported by the Israel Science Foundation (grant no. 578-01) and the United States-Israel Binational Agricultural Research and Development Fund (BARD) (grant no. US-3265-01).

\section{LITERATURE CITED}

Arnold, D. L., Pitman, A., and Jackson R. W. 2003. Pathogenicity and other genomic islands in plant pathogenic bacteria. Mol. Plant Pathol. 4:404-420.

Ausubel, F. M., Brent, R., Kingston, R. E., Moore, D. D., Seidman, J. G., Smith, J. A., and Struhl, K., eds. 1995. Current Protocols in Molecular Biology. John Wiley \& Sons, Inc., New York.

Bashyam, D. M., and Hasnain, S. E. 2004. The extracytoplasmic function sigma factors: Role in bacterial pathogenesis. Infect. Genet. Evol. 4:301-308.

Burr, T. J., Katz, B. H., Abawi, G. S., and Crosier, D. C. 1991. Comparison of tumorigenic strains of Erwinia herbicola isolated from table beet with E. h. gypsophilae. Plant Dis. 75:855-858.

Callaci, S., Heyduk, E., and Heyduk, T. 1999. Core RNA polymerase from $E$. coli induces a major change in the domain arrangement of sigma 70 subunit. Mol. Cell 9:527-539.

Campbell, E. A., Muzzin, O., Chlenov, M., Sun, J., Olson, C. A., Weinman, O.,
Trester-Zedlitz, M. L., and Darst, S. A. 2002. Structure of the bacterial RNA polymerase promoter specificity sigma subunit. Mol. Cell 9:527539.

Clark, E., Manulis, S., Ophir, Y., Barash, I., and Gafni, Y. 1993. Cloning and characterization of iaaM and iaaH from Erwinia herbicola pathovar gypsophilae. Phytopathology 83:234-240.

Cooksey, D. A. 1986. Galls of Gypsophila paniculata caused by Erwinia herbicola. Plant Dis. 70:464-468.

Ezra, D, Barash, I., Valinsky, L., and Manulis, S. 2000. The dual function in virulence and host range restriction of a gene isolated from the pPA$\mathrm{TH}_{\mathrm{Ehg}}$ plasmid of Erwinia herbicola pv. gypsophilae. Mol. PlantMicrobe Interact. 13:693-698.

Ezra, D, Barash, I., Weinthal, D. M., Gaba, V., and Manulis S. 2004. pthG from Pantoea agglomerans pv. gypsophilae encodes an avirulence effector that determines incompatibility in multiple beet species. Mol. Plant Pathol. 5:105-114.

Fouts, D. E, Abramovitch, R. B., Alfano, J. R., Baldo, A. M., Buell, C. R., Cartinhour, S., Chatterjee, A. K., D’Ascenzo, M., Gwinn, M. L. Lazarowitz, S. G., Lin, N-C., Martin, G. B., Rehm, A. S., Schneider D. J., van Dijk, K., Tang, X., and Collmer, A. 2002. Genome wide identification of Pseudomonas syringae pv. tomato DC3000 promoters controlled by the HrpL alternative sigma factor. Proc. Natl. Acad. Sci. U.S.A. 99:2275-2280.

Gafni, Y., Manulis, S., Kunik, T., Lichter, A., Barash, I., and Ophir, Y. 1997. Characterization of the auxin synthesis genes of Erwinia herbicola pv. gypsophilae. Isr. J. Plant Sci. 45:279-284.

Greenberg, J. T., and Vinatzer, B. A. 2003. Identifying type III effectors of plant pathogens and analyzing their interaction with plant cells. Curr. Opin. Microbiol. 6:20-28.

Guo, M., Manulis, S., Mor, H., and Barash, I. 2002. The presence of diverse IS elements and an $a v r P p h D$ homologue that acts as a virulence factor on the pathogenicity plasmid of Erwinia herbicola pv. gypsophilae. Mol. Plant-Microbe Interact. 15:709-716.

Guzman, L. M., Belin, D., Carson, M. J., and Beckwith, J. 1995. Tight regulation, modulation, and high level expression by vectors containing the arabinose PBAD promoter. J. Bacteriol. 177:4121-4130.

Hacker, J., and Kaper, J. B. 1999. The concept of pathogenicity islands. Pages 1-11 in: Pathogenicity Islands and Other Mobile Virulence Elements. J. B. Kaper and J. Hacker, eds. American Society for Microbiology Press, Washington, D.C.

Helmann, J. D., and Chamberlin, M. J. 1988. Structure and function of bacterial sigma factors. Annu. Rev. Biochem. 57:839-872.

Hutcheson, S. W., Bretz, J., Sussan, T., Jin, S., and Pak, K. 2002. Enhancerbinding proteins HrpR and HrpS interact to regulate hrp-encoded type III protein secretion in Pseudomonas syringae strains. J. Bacteriol. 183:5589-5598.

Innes, R. W., Bent, A. F., Kunkel, B. N., Bisgrove, S. R., and Staskawicz, B. J. 1993. Molecular analysis of avirulence gene $a v r R p t 2$ and identification of a putative regulatory sequence common to all known Pseudomonas syringae avirulence genes. J. Bacteriol. 175:4859-4869.

Jin, Q., Thilmony, R., Zweiesler-Vollick, J., and He, S-Y. 2003. Type III protein secretion in Pseudomonas syringae. Microbes Infect. 5:301310.

Kovach, M. E., Elzer, P. H., Hill, D. S., Robertson, G. T., Farris, M. A. R, Roop, M. I., and Peterson K. M. 1995. Four new derivatives of the broad host range cloning vector pBBR1MCS carrying different antibiotic resistance cassettes. Gene 166:175-176.

Lichter, A., Barash, I., Valinsky, L., and Manulis, S. 1995. The genes involved in cytokinin biosynthesis in Erwinia herbicola pv. gypsophilae: Characterization and role in gall formation. J. Bacteriol. 177:44574465.

Lichter, A., Manulis, S., Valinsky, L., Karniol, B., and Barash, I. 1996. IS1327, a new insertion-like element in the pathogenicity-associated plasmid of Erwinia herbicola pv. gypsophilae. Mol. Plant-Microbe Interact. 9:98-104

Lindgren, P. B. 1997. The role of hrp genes during plant-bacterial interactions. Annu. Rev. Phytopathol. 35:129-152.

Lonetto, M, Gribskov, M., and Gross, C. A. 1992. The sigma 70 family: Sequence conservation and evolutionary relationships. J. Bacteriol 174:3843-3849.

Lonetto, M. A., Brown, K. L., Rudd, K. E., and Buttner, M. J. 1994. Analysis of Streptomyces coelicolor sigE gene reveals the existence of the subfamily of eubacterial RNA polymerase factors involved in the regulation of extracytoplasmic functions. Proc. Natl. Acad. Sci. U.S.A. 91:7573-7577.

Manulis, M., and Barash, I. 2003a. The Molecular basis for transformation of an epiphyte into a gall-forming pathogen as exemplified by Erwinia herbicola pv. gypsophilae. Pages 19-52 in: Plant-Microbe Interactions. G. Stacey and N. Keen, eds. American Phytopathological Society. St. Paul, MN, U.S.A. 
Manulis, S., and Barash, I. 2003b. Contribution of virulence determinants from Pseudomonas and other bacteria to hrp-dependent gall formation by Erwinia herbicola pv. gypsophilae. Pages 373-381 in: Pseudomonas syringae and Related Pathogens. N. S. Iacobelis, A. Collmer, S. W. Hutcheson, J. W. Hansfield, C. E. Morris, J. Murillo, N. W. Schaad, D. E. Staed, G. Surico, and M. S. Ullrich, eds. Kluwer Academic Publishers, Dordrecht, The Netherlands.

Manulis, S., Gafni, Y., Clark, E., Zutra, D., Ophir, Y., and Barash, I. 1991. Identification of a plasmid DNA probe for detection of Erwinia herbicola pathogenic on Gypsophila paniculata. Phytopathology 81:54-57.

Manulis, S., Haviv-Chesner, A., Brandl, M. T., Lindow, E., and Barash, I. 1998. Differential involvement of indole-3-acetic acid biosynthetic pathways in pathogenicity and epiphytic fitness of Erwinia herbicola pv. gypsophilae. Mol. Plant-Microbe Interact. 11:634-642.

Merighi, M., Majerczak, D. R., Stover, E. H., and Coplin, D. L. 2003. The HrpX/HrpY two-component system activates hrpS expression, the first step in the regulatory cascade controlling the Hrp regulon in Pantoea stewartii subsp. stewartii. Mol. Plant-Microbe Interact. 16:238-248.

Minogue, T. D., Wehland-von Trebra, M., Bernhard, F., and von Bodman, S. B. 2002. The autoregulatory role of EsaR, a quorum-sensing regulator in Pantoea stewartii ssp. stewartii: Evidence for a repressor function. Mol. Microbiol. 44:1625-1635.

Mor, H, Manulis, S., Zuc, M., Nizan, R., Coplin, D. L., and Barash, I 2001. Genetic organization of the hrp gene cluster and dspAE/BF operon in Erwinia herbicola pv. gypsophilae. Mol. Plant-Microbe Interact. 14:431-436.

Nizan, R, Barash, I., Valinsky, L., Lichter, A., and Manulis, S. 1997. The presence of $h r p$ genes on the pathogenicity-associated plasmid of the tumorigenic bacterium Erwinia herbicola pv. gypsophilae. Mol. PlantMicrobe Interact. 10:677-682.

Nizan-Koren, R., Manulis, S., Mor, H., Iraki, N. M., and Barash, I. 2003. The regulatory cascade that activates the Hrp regulon in Erwinia herbicola pv. gypsophilae. Mol. Plant-Microbe Interact. 15:I249260

Sambrook, J., Fritsch, E. F., and Maniatis, T. 1989. Molecular Cloning: A Laboratory Manual, 2nd ed. Cold Spring Harbor Laboratory Press, Cold Spring Harbor, NY, U.S.A.

Schneider, T. D., and Stephens, R. M. 1990. Sequence logos: A new way to display consensus sequences. Nucleic Acids Res. 18:6097-6100.

Severinova, E., Severinov, K., Fenyo, D., Marr, M., Brody, E. M., Roberts, J. W., Chait, B. T., and Darst, S. A. 1996. Domain organization of the
Escherichia coli RNA polymerase sigma 70 subunit. J. Mol. Biol 263:637-647.

Shen, H., and Keen, N. T. 1993. Characterization of the promoter of avirulence gene D from Pseudomonas syringae pv. tomato. J. Bacteriol. 175:5916-5924.

Staskawicz, B., Dahlbeck, D., Keen, N., and Napoli, C. 1987. Molecular characterization of cloned avirulence genes from race 0 and race 1 of Pseudomonas syringae pv. glycinea. J. Bacteriol. 169:5789-5794.

Tiedman, A., and Smith, J. M. 1988. LacZY gene fusion cassettes with KanR resistance. Nucleic Acid Res. 16:3587-3593.

Turkov, M., Rashi, S., Zilberberg, N., Gordon, D., Ben Khalifa, R., Stankiewicz, M., Pelhate, M., and Gurevitz, M. 1997. In vitro folding and functional analysis of an anti-insect $M$ selective scorpion depressant neurotoxin produced in Escherichia coli. Prot. Express. Purif. 10:123-131.

Valinsky, L., Manulis, S., Nizan, R., Ezra, D., and Barash, I. 1998. A pathogenicity gene isolated from the pPATH of Erwinia herbicola pv. gypsophila determines host specificity. Mol. Plant-Microbe Interact. 11:753-762.

Valinsky, L., Barash, I., Chalupowicz, L., Ezra, D., and Manulis, S. 2002a Regulation of $h s v G$, a host-specific virulence gene from Erwinia herbicola pv. gypsophilae. Physiol. Mol. Plant Pathol. 60:19-29.

Valinsky, L., Nisan, I., Tu, X., Nisan, G., Rosenshine, I., Hansky, E., Barash, I., and Manulis, S. 2002b. A host-specific virulence protein of Erwinia herbicola pv. gypsophilae is translocated into human epithelial cells by the type III secretion system of enteropathogenic Escherichia coli. Mol. Plant Pathol. 3:97-101.

Wei, Z. M., Kim, J. F., and Beer, S. V. 2000. Regulation of hrp genes and type III protein secretion in Erwinia amylovora by HrpX/HrpY, a novel two component system, and HrpS. Mol. Plant-Microbe Interact. 13:1251-1262.

Wilson, M. J., McMorran, B. J., and Lamont, I. L. 2001. Analysis of promoters recognized by PvdS, an extracytoplasmic-function factor from Pseudomonas aeruginosa. J. Bacteriol. 183:2151-2155.

Xiao, Y., and Hutcheson, S. W. 1994. A single promoter sequence recognized by newly identified alternate sigma factor direct expression of pathogenicity and host range determinants in Pseudomonas syringae. J. Bacteriol. 176:3089-3091.

Zwiesler-Vollick, J., Plovanich-Jones, A. E., Nomura, K., Bandyopadhyay, S., Joardar, V., Kunkel, B. N., and He, S. Y. 2002. Identification of novel hrp-regulated genes through functional genomic analysis of the Pseudomonas syringae pv. tomato DC3000 genome. Mol. Microbiol. 45:12071218 . 